\title{
Palynodating of subsurface sediments, Raniganj Coalfield, Damodar Basin, West Bengal
}

\author{
Srikanta Murthy ${ }^{1, *}$, B Chakraborti ${ }^{2}$ and M D Roy ${ }^{2}$ \\ ${ }^{1}$ Birbal Sahni Institute of Palaeobotany, 53 University Road, Lucknow 226 007, India. \\ ${ }^{2}$ Coal Wing, Geological Survey of India, Kolkata 700 091, India. \\ *e-mail: Srikanta_murthy22@rediffmail.com
}

The Gondwana sediments comprising fine-grained shales, carbonaceous shales, sandstones and the coal horizon in borecore RT-4 (approximately $547.00 \mathrm{~m}$ thick) from Tamra block, Raniganj Coalfield, Damodar Basin, are analyzed palynologically. Based on the distribution pattern of marker palynotaxa, two assemblage zones are identified. In the Barren Measures Formation, dominance of enveloping monosaccate (Densipollenites) along with striate bisaccate (Striatopodocarpites, Faunipollenites) pollen taxa, and the FAD's of Kamthisaccites and Arcuatipollenites observed at 30.75, have equated this strata $(30.75-227.80 \mathrm{~m}$ thick) with the Raniganj Formation of Late Permian in age. Downwards in the Barakar Formation, between $423.80-577.70 \mathrm{~m}$ depths, an abundance of non-striate (Scheuringipollenites) and striate (Faunipollenites and Striatopodocarpites) bisaccate pollen taxa is observed, that dates late Early Permian in age.

Fair occurrences of hyaline, distorted and blackish-brown plant matter is observed within 231.00-408.40 m depths. Present study infers the existence of the Raniganj Formation in the lithologically delimited Barren Measures Formation in the study area, and the underlying unproductive strata (approx. $177.40 \mathrm{~m}$ ) might represent the part of the Barren Measures Formation.

\section{Introduction}

The Gondwana sediments in Damodar Basin occur in isolated coalfields in E-W trending linear belt (Gee 1932). The Raniganj Coalfield is the easternmost depository within the Damodar Basin, the semi-elliptical, elongated in shape, and covers an area of ca $3000 \mathrm{~km}^{2}$ and lies between latitudes $23^{\circ} 03^{\prime}$ and $23^{\circ} 51^{\prime} \mathrm{N}$ and longitudes $86^{\circ} 42^{\prime}$ and $87^{\circ} 28^{\prime}$ E. Previously, much palynological studies had already been done in different blocks of the Raniganj Coalfield (Bharadwaj and Tiwari 1977; Tiwari and Meena 1992). Moreover, in Trans-Damodar area of the Raniganj Coalfield (figure 1), bore-core RT-4 has intersected the Barren Measures Formation into the Barakar Formation. The main objective of present study is the palynodating of the subsurface Permian deposits.

\section{Geological setting}

The Gondwana rocks in the Raniganj Coalfield are represented by Talchir, Barakar, Barren Measures, Raniganj and Panchet formations. Borehole RT-4 is drilled by GSI in Tamra block of Raniganj Coalfield, that is located in the Trans-Ajay area in the northern part of this coalfield (figure 1). The Gondwana rocks in the Tamra block lie over a basement, consisting of magmatic gneisses of the Precambrian. Here, the Barakar Formation underlies the Barren Measures Formation (figure 2). The Talchir rocks are not exposed but sporadically intersected in the borehole, that is suggestive of patchy developments within disconnected shallow depressions over the basement. Lithostratigraphy intersected in this borehole is given in table 1.

Keywords. Tamra block, palynomorphs, Barren Measures Formation, Barakar Formation, Damodar Basin, Permian. 


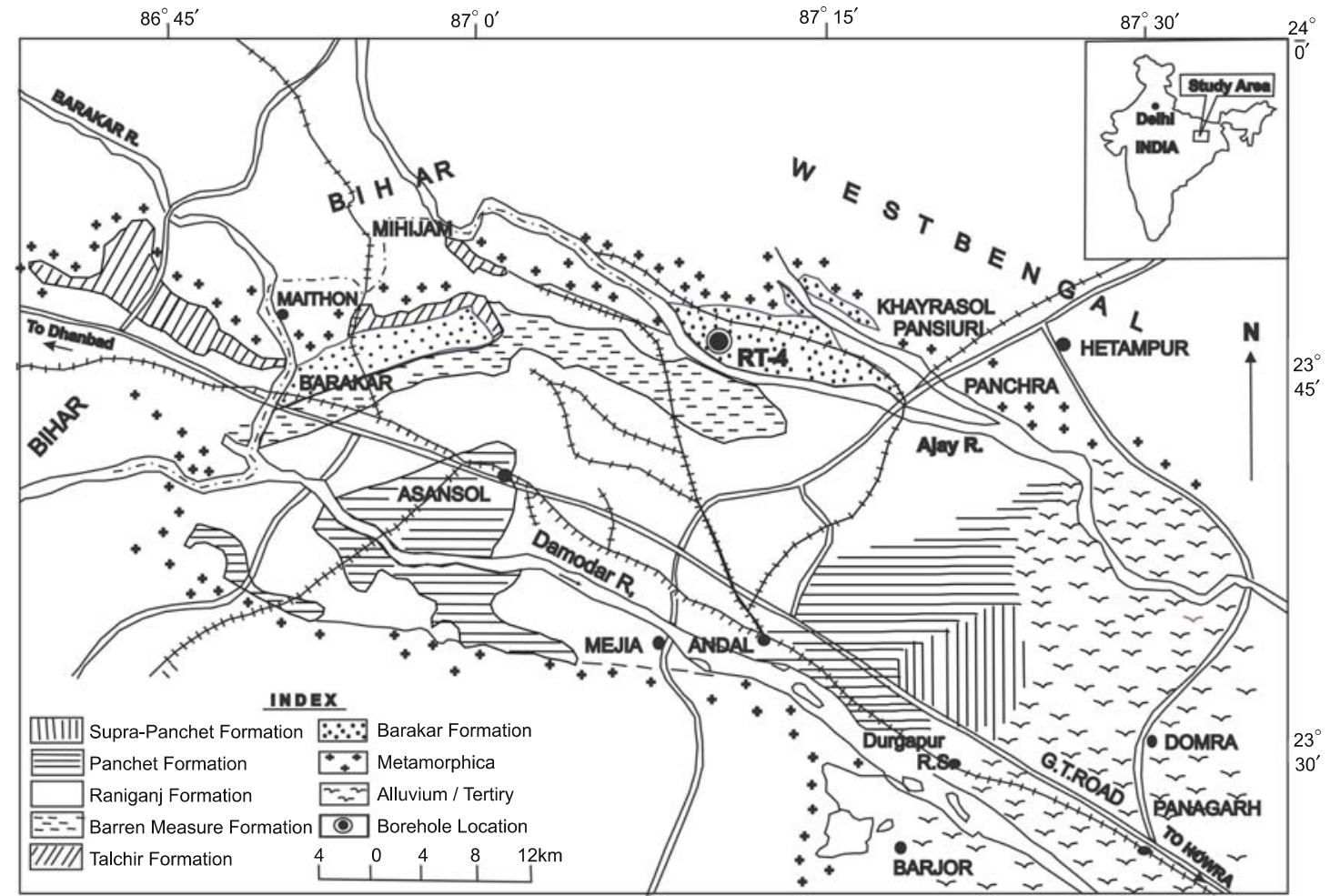

(a)

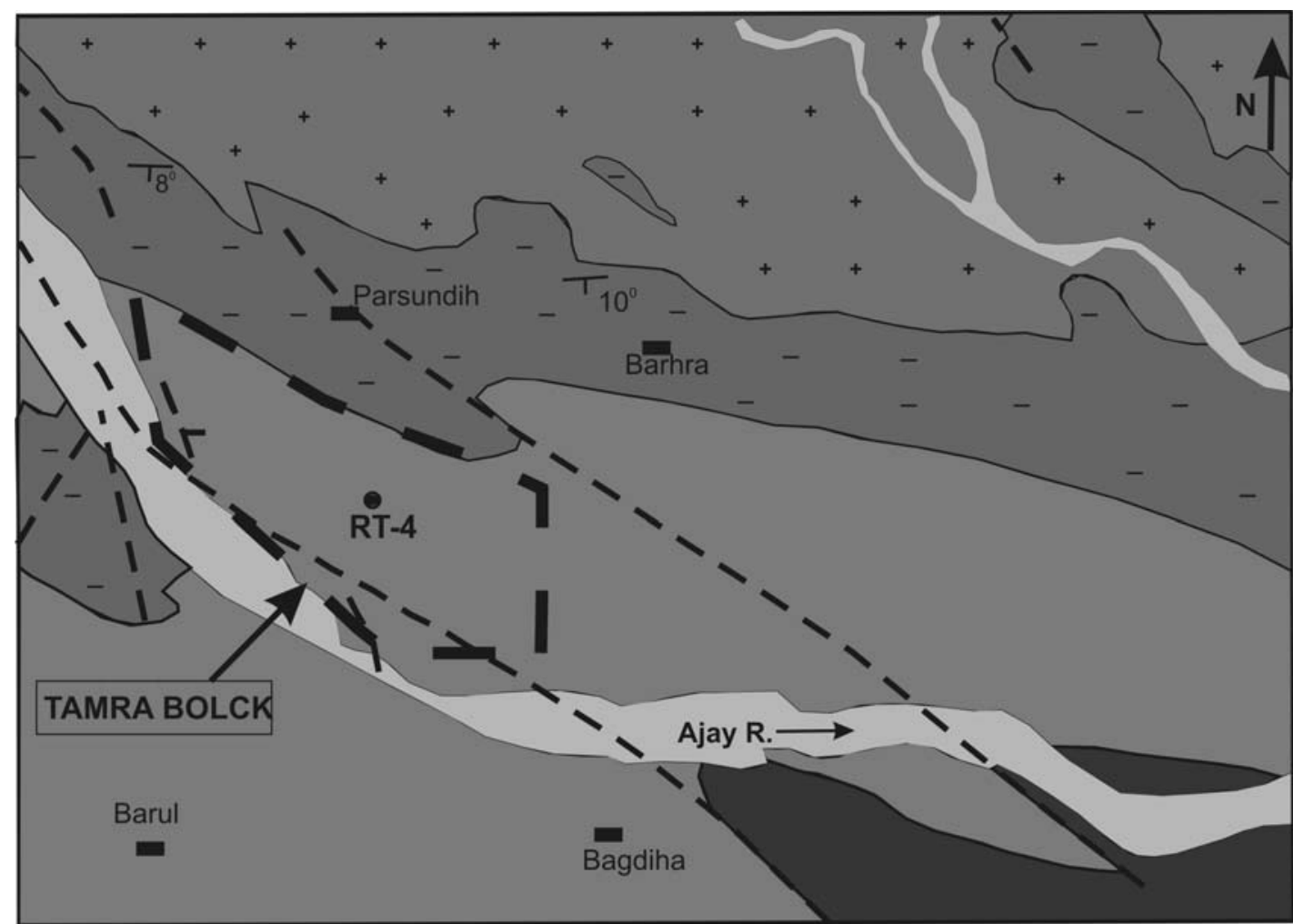

Raniganj Formation

Barren Measures Formation

Barakar Formation

(b)

Basement

Block boundary

- Location of Borehole RT-4

Figure 1. (a) Geological map of Raniganj Coalfield showing the location of borehole RT-4. (b) Geological map of Tamra block, Raniganj Coalfield (after GSI). 


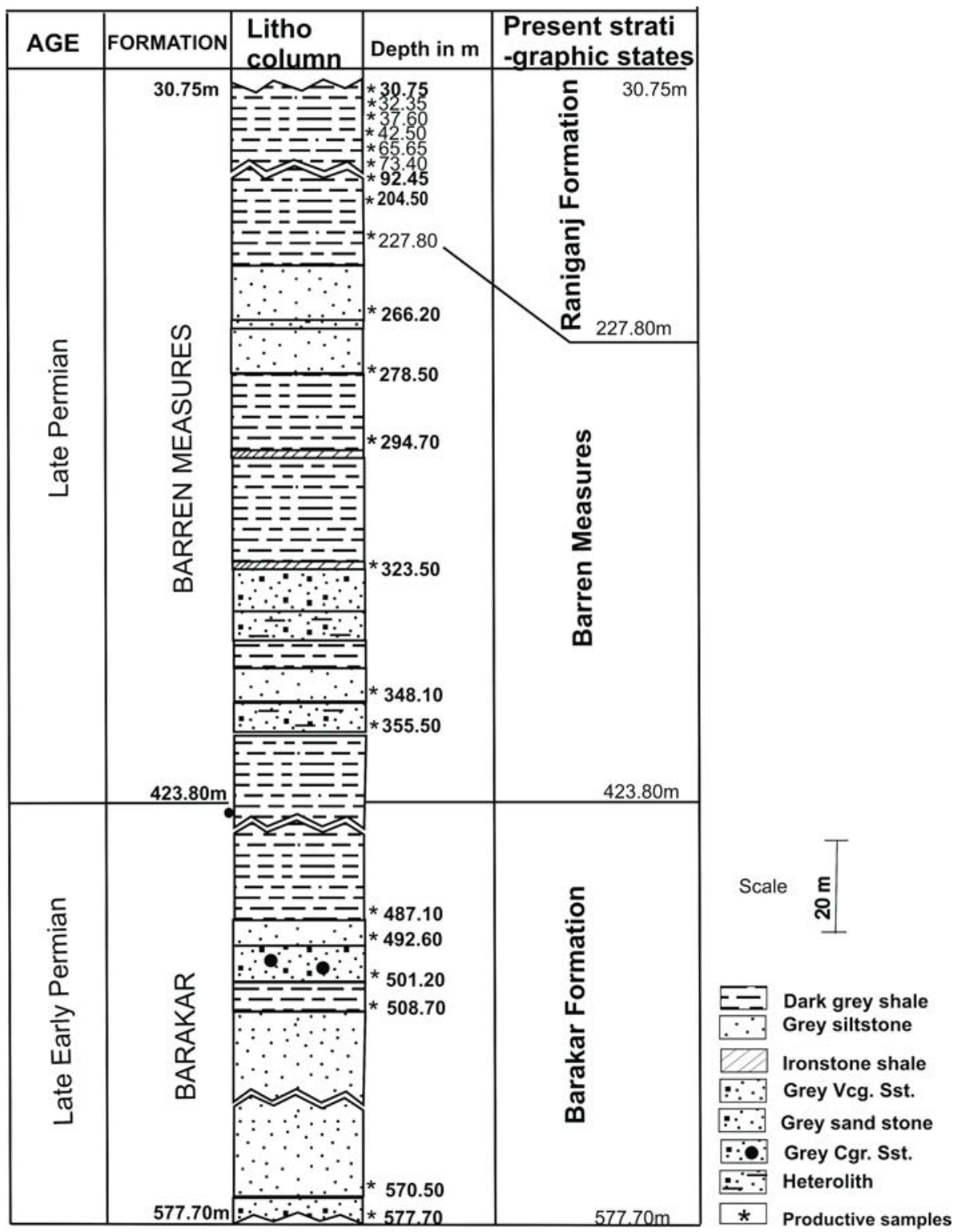

Figure 2. Formational units in borehole RT-4, Tamra block, Raniganj Coalfield.

Table 1. Generalized litho sequence intersected in the borehole RT-4, Raniganj Coalfield (Dutta 2003).

\begin{tabular}{lll}
\hline Age & Formation & \multicolumn{1}{c}{ Lithology } \\
\hline & Barren Measures & $\begin{array}{l}\text { Dark grey to black, micaceous or carbonaceous, fissile } \\
\text { shale with ferruginous laminae and thin bands of dense, } \\
\text { hard, crypto crystaline clay iron stone, rarely interbanded } \\
\text { with fine grained sandstone. }\end{array}$ \\
& & $\begin{array}{l}\text { Very coarse-to-medium grained, arkosic sandstone, often } \\
\text { Permian }\end{array}$ \\
& Baraks bedded; grey and corbonaceous shale, at times inter \\
& & banded with fine grained sandstone, fine clay lenses and \\
& & coal seams, pebbly and carbonaceous in lower part. \\
\hline
\end{tabular}

\section{Material and method}

From 121 rock samples in the borehole RT-4 (figure 2), only 88 samples have yielded the spores and pollen. Sediments are processed by standard maceration technique that is $50 \mathrm{~g}$ of sediments taken and crushed, were first treated with $40 \%$ hydrofluoric acid for 3-4 days (to remove 
Table 2. List of spore-pollen species identified in borehole RT-4, Raniganj Coalfield.

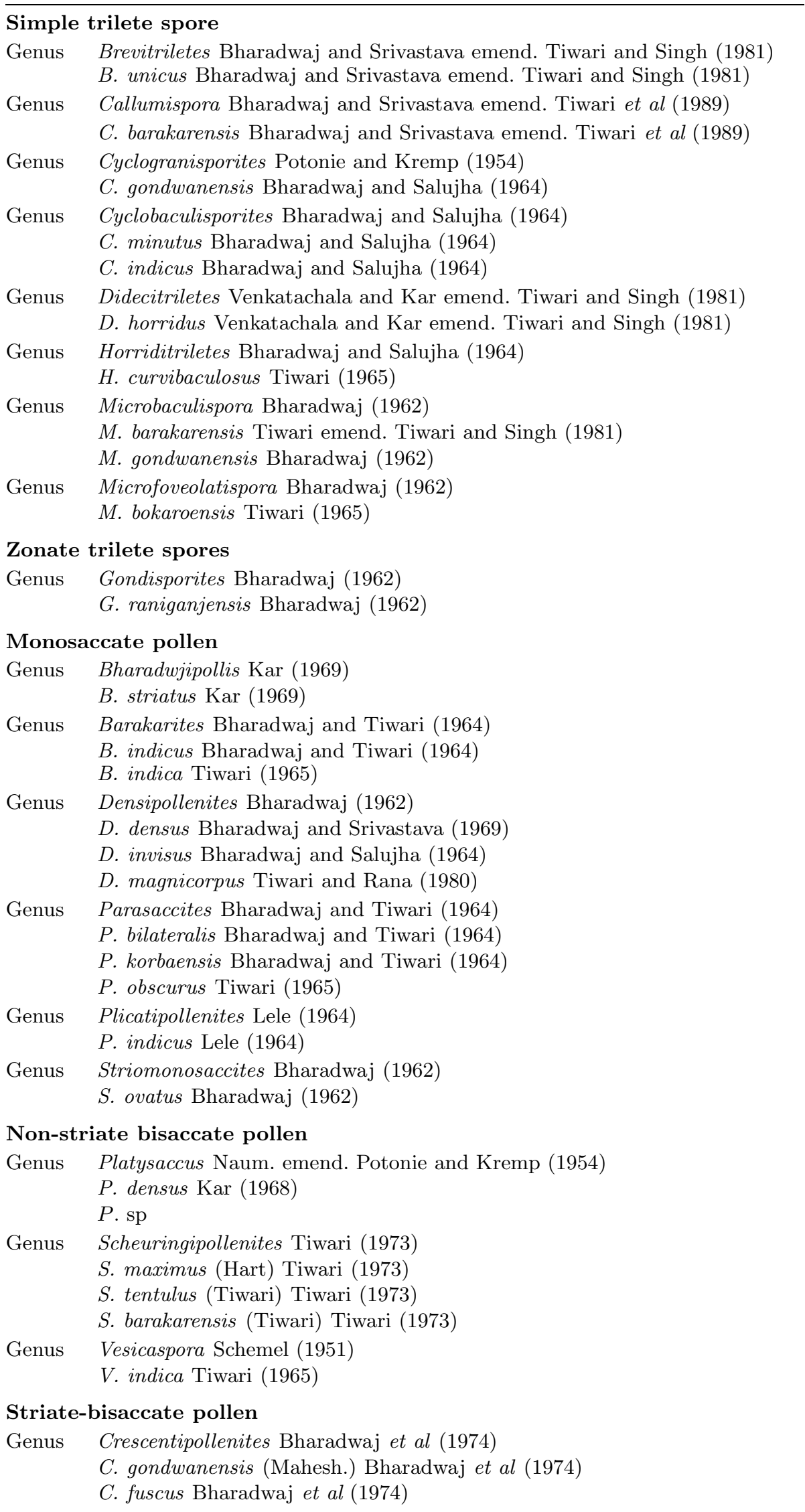


Table 2. (Continued).

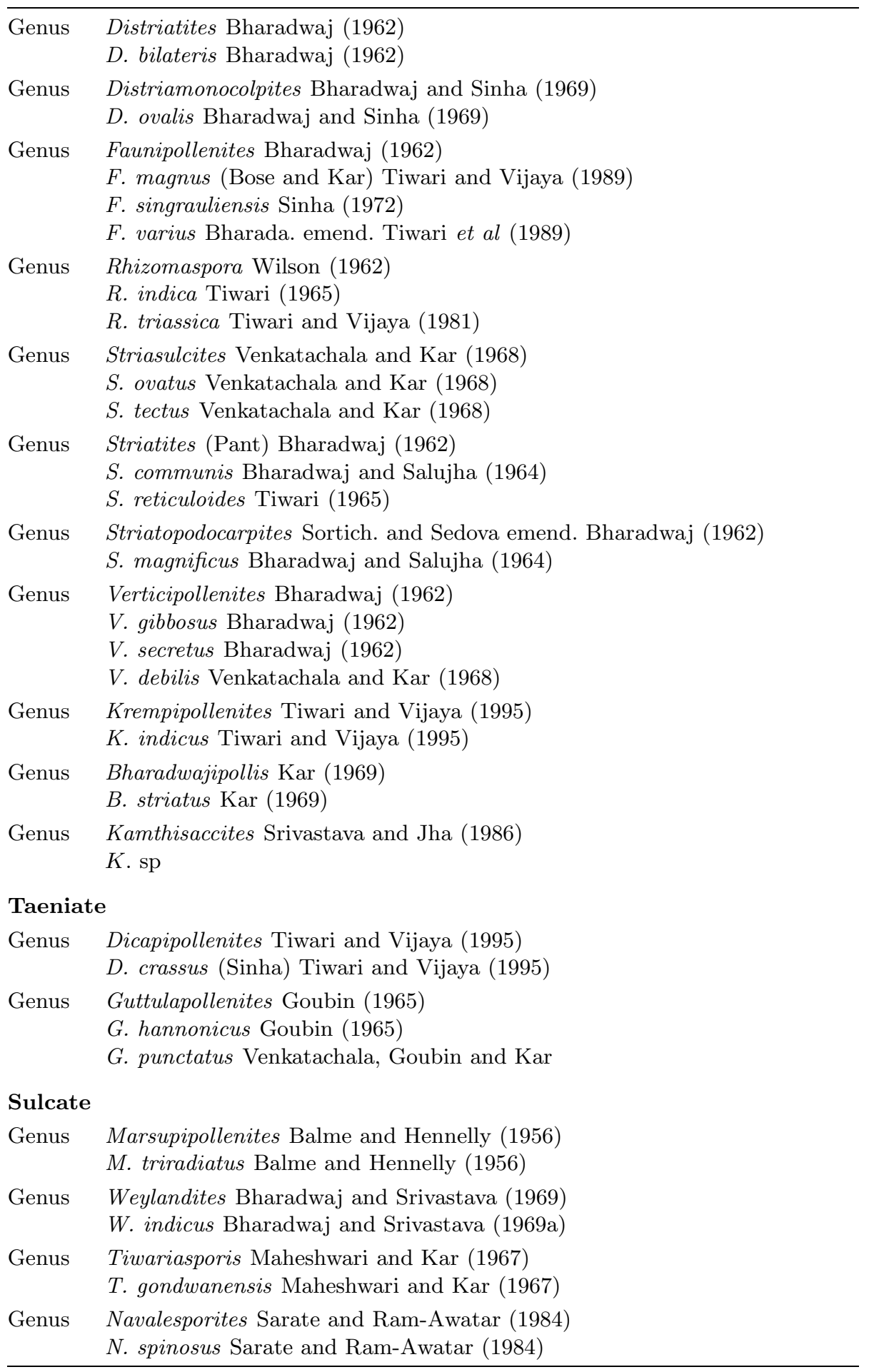

silica material), and then followed by Nitric acid for 5 days (digestion of humic matter). Further to this, sediments were treated with $10 \%$ potassium hydroxide to release the humus. The maceral were then mounted in polyvinyl alcohol and canada balsam for each sample and five slides were prepared. Microscopic observation (Olympus BX61model) is done from each sample at species level for microfloral analysis and the species identified are listed in table 2.

\section{Palynological observation}

On the basis of qualitative and quantitative analyses of the spores and pollen taxa, two palynoassemblages have been identified (table 3 and figure 3 ). 
Table 3. Palynodating in the borehole RT-4 (30.75-577.70 m depth), Raniganj Coalfield.

\begin{tabular}{|c|c|c|c|c|c|c|}
\hline Age & $\begin{array}{l}\text { Lithostrati- } \\
\text { garaphic } \\
\text { formation }\end{array}$ & $\begin{array}{l}\text { Depth } \\
(\mathrm{m})\end{array}$ & $\begin{array}{l}\text { Assemblage } \\
\text { identified }\end{array}$ & $\begin{array}{l}\text { Placement in } \\
\text { palynozonation }\end{array}$ & $\begin{array}{c}\text { Age } \\
\text { affiliation }\end{array}$ & Remarks \\
\hline \multirow{2}{*}{ 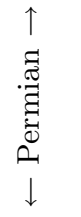 } & $\begin{array}{l}\text { Barren } \\
\text { Measures }\end{array}$ & $30.75-227.80$ & Assemblage I & $\begin{array}{c}\text { Densipollenites } \\
\text { magnicorpus }\end{array}$ & $\begin{array}{l}\text { Late } \\
\text { Permian }\end{array}$ & $\begin{array}{l}\text { Equated with } \\
\text { Raniganj } \\
\text { Formation }\end{array}$ \\
\hline & Barakar & $419.95-577.70$ & Assemblage II & $\begin{array}{l}\text { Scheuringipollenites } \\
\text { barakarensis }\end{array}$ & $\begin{array}{l}\text { Late Early } \\
\text { Permian }\end{array}$ & $\begin{array}{l}\text { Barakar } \\
\text { Formation }\end{array}$ \\
\hline
\end{tabular}

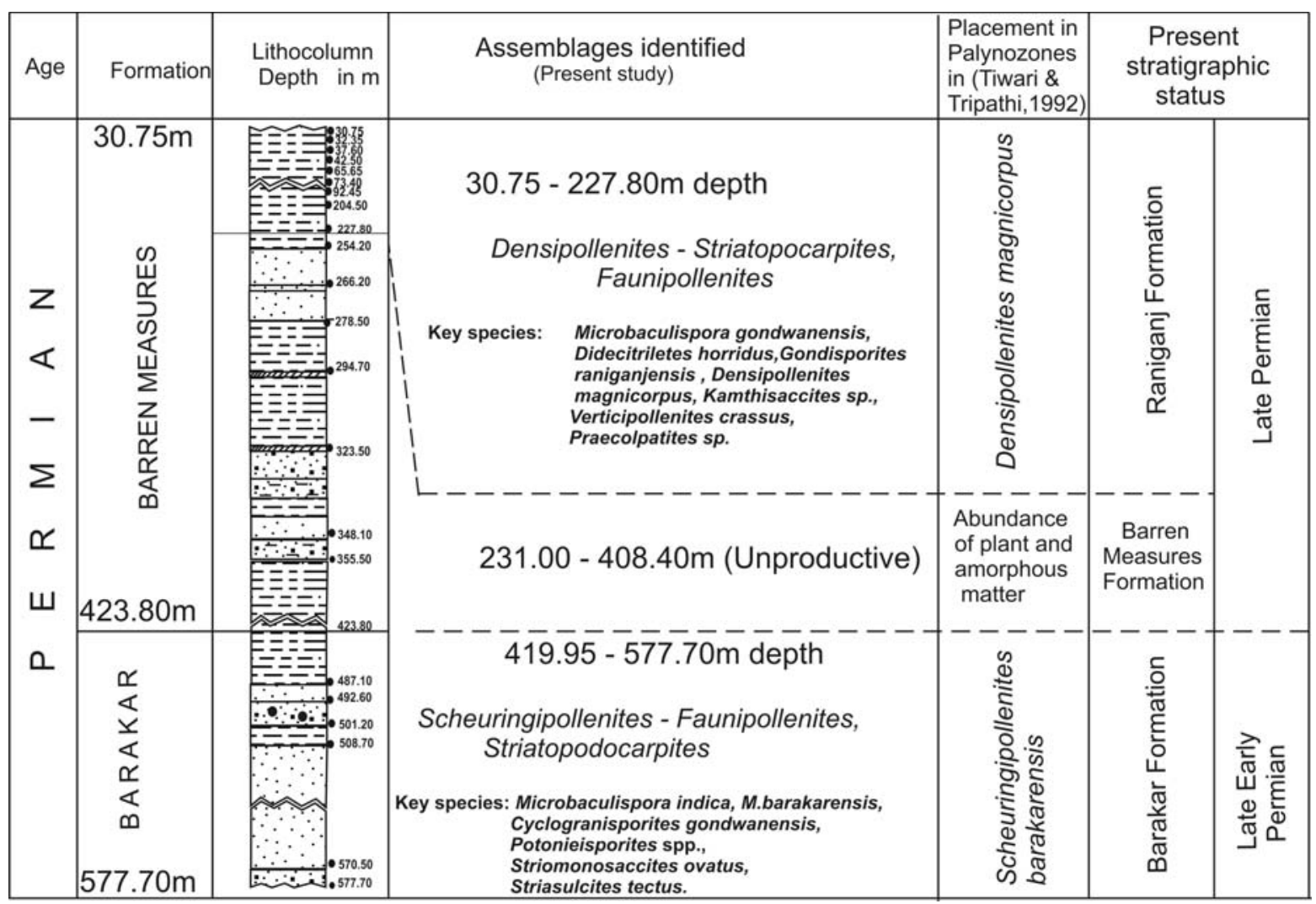

Figure 3. Palynoassemblage identified in borehole RT-4, Raniganj Coalfield, Damodar Basin and biostratigraphic status of Barakar and Barren Measures formations.

The relative occurrences of the taxa vary from rare (less than $1 \%)$, common (1-5\%), fair $(5-10 \%)$ to an abundance (11-25\%) and dominant (more than $25 \%)$ in an assemblage.

\subsection{Assemblage I}

Depth: 227.80-30.75 m (Grey shale)

Dominance of Densipollenites-Striatopodocarpites, Faunipollenites

The assemblage recovered in fine grained dark grey shales intercalated with siltstone in $196.35 \mathrm{~m}$ thick strata $(30.75-227.80 \mathrm{~m})$ is represented by the dominance of Densipollenites followed by subdominance of Striatopodocarpites and Faunipollenites. The other significant species include Cyclogranisporites gondwanensis, Cyclobaculisporites indicus, Platysaccus densus, Crescentipollenites spp, Weylandites indicus, Striamonosaccites ovatus, Distriatites bilateris, Verticipollenites oblongus and Rhizomaspora indica.

Characteristic species: Crescentipollenites gondwanensis, Gondisporites raniganjensis, Microbaculispra gondwanensis, Didecitriletes horridus, Indotriradites mammilatus, Striamonosaccites ovatus, Guttulapollenites hannonicus, Striasulcites ovatus, Distriomocolpites ovalis, Tiwariasporis gondwanensis, Marsupipollenites triaradites. FAD's of Kamthisaccites sp., Arcuatipollenities sp., Praecolpatites sp. 

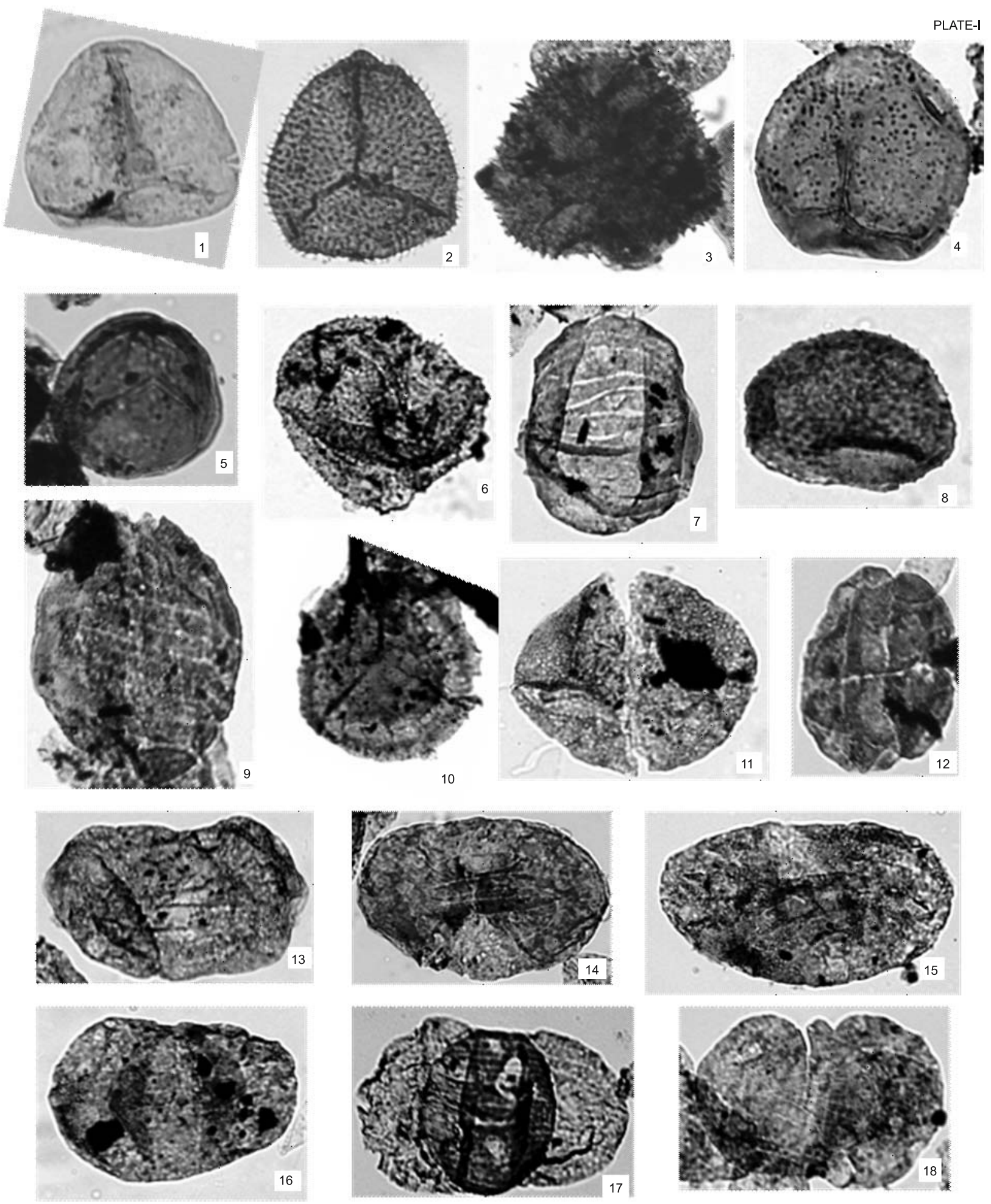

Plate 1. (1) Lacinitriletes barakarensis Venkatachala and Kar (1965); (2) Didecitriletes horridus Venkatachala and Kar emend. Tiwari and Singh (1981); (3) Brevitriletes uniclus Bharadwaj and Srivastava emend. Tiwari and Singh (1981); (4) Punctatisporites morosus Venkata and Kar (1968); (5) Callumispora barakarensis Bharadwaj and Srivastava emend. Tiwari et al (1989); (6) Cyclobaculisporites minutes Bharadwaj and Salujha (1964); (7) Striasulcites tectus Venkatachala and Kar (1968); (8) Navalesporites spinosus Sarate and Ram-Awatar (1984); (9) Distriamonocolpites ovalis Bharadwaj and Sinha (1969); (10) Gondisporites raniganjensis Bharadwaj (1962); (11) Scheuringipollenites barakarensis (Tiwari) Tiwari (1973); (12) Guttallapollenites punctatus Venk, Goubin and Kar; (13) Faunipollenites magnus (Bose and Kar) Tiwari and Vijaya (1989); (14) Faunipollenites singrauliensis Sinhas (1972); (15) Faunipollenites varius Bharada emend. Tiwari et al (1989); (16) Crescentipollenites fuscus Bharad et al (1974); (17) Striatopodocarpites magnicarpus Bharadwaj and Tiwari (1964); (18) Striatites reticuloids Tiwari (1965). 

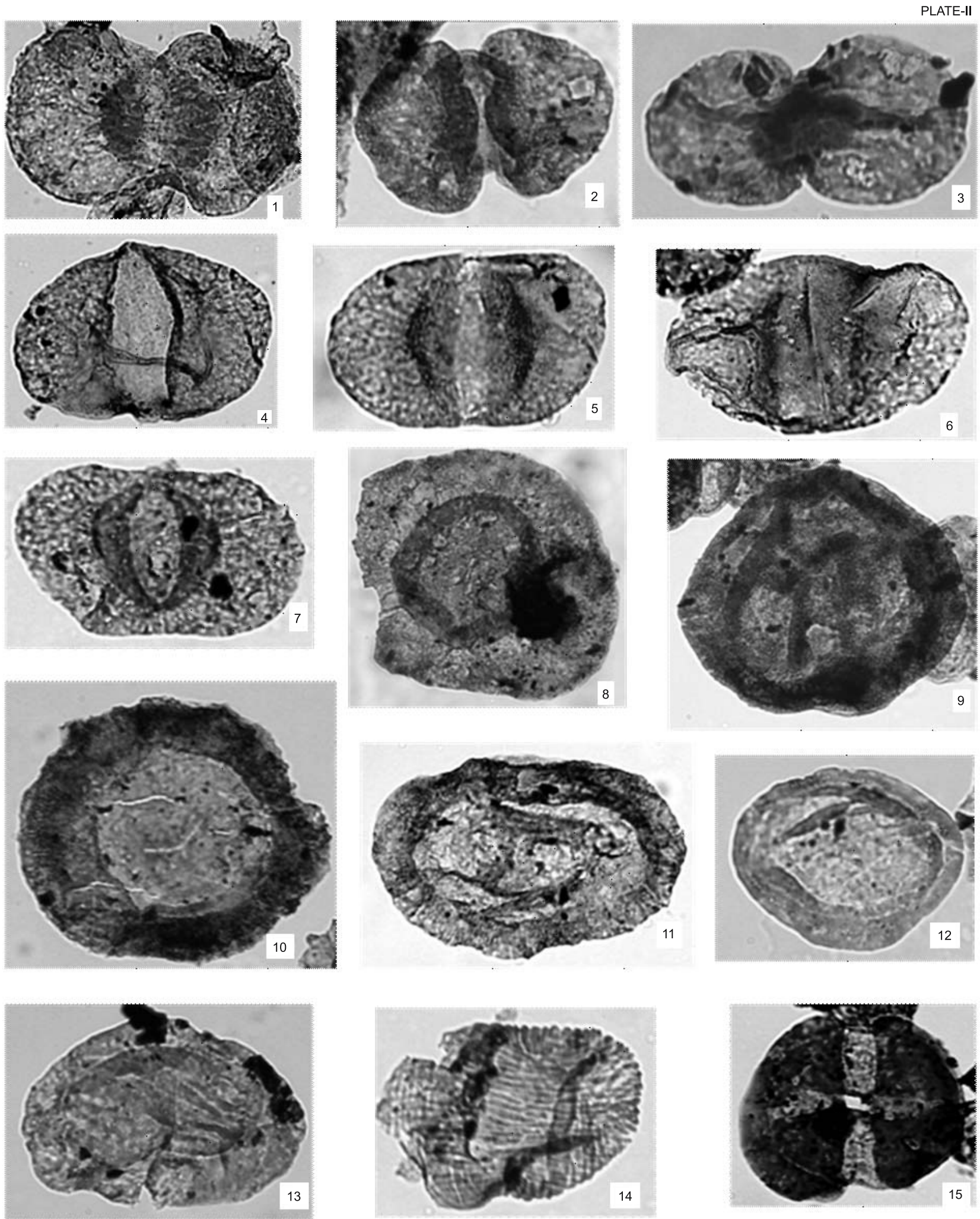

Plate 2. (1) Stritites communis Bharadwaj and Salujha (1964); (2) Verticipollenites debilis Venkatachala and Kar (1968); (3) Rhizomaspora indica Tiwari (1964); (4) Klausipollenites sulcatus Kar (1972); (5) Alisporites plicatus Kar et al (1972); (6) Satsangisaccites nidpurensis Bharadwaj and Srivastava (1964); (7) Primuspollenites levis Tiwari (1964); (8) Plicatipollenites indicus Lele (1964); (9) Densipollenites magnicarpus Tiwari and Rana (1980); (10) Parasaccites obscurus Tiwari (1965); (11) Barakarites indicus Bharadwaj and Tiwari (1964); (12) Bharadwajiapollis striatus Kar (1969);

(13) Kamthisaccites kamthiensis Srivastava and Jha (1986); (14) Weylandites indicus Bharadwaj and Srivastava (1969a);

(15) Dicapipollenites crassus Tiwari and Vijaya (1995). 
Palynoassemblage-I, compares with the Densipollenites magnicorpus palynozone of Tiwari and Tripathi (1992) in having relatively fair occurrence of D. magnicorpus and the FAD's of Arcuatipollenites sp. and Kamthisaccites sp. As shown in figure 3 , the characteristic age marker species suggest a younger status to palynoassemblage-I in the Late Permian.

Palynodating: Latest Permian Formation: Raniganj Formation

\subsection{Assemblage II}

Depth: 419.95-577.70 m (Grey shales and interbeded with sandstone)

Dominance of Scheuringipollenites-Faunipollenites, Striatopodocarpites

The carbonaceous dark grey shales intermixed with sandstones facies (346.60 $\mathrm{m}$ thick strata) in the coal horizon have yielded spores and pollen at various depths. Dominance of Scheuringipollenites along with Faunipollenites is significant. The other elements are Striasulcites ovatus, Striatites spp, Barakarites indicus, Callumispora barakarensis, Cyclogranisporites gondwanensis, Densipollenites indicus, Rhizomaspora indica, Verticipollenites densus, Verticipollenites crassus, Guttulapollenites punctatus, Primuspollenites levis and Striatites communis. Trilete spores Horriditriletes curvibaculosus, Microfoveolatispora bokaroensis are less in number. And the rare occurrences of Striamonosaccites ovatus, Dicappipollentites crassus have also been observed.

Characteristic species: Scheuringipollenites barakarensis, Microbaculispora barakarensis, Horriditriletes curvibaculosus, Barakarites indica, Vesicaspora indica, Verticipollenites secretus, V. gibbosus.

Besides, the occurrences of monosaccate pollen Potoniesporites neglectus and Parasaccites korbaensis are noteworthy in the assemblage. This reflects humid climate. This composition of palynoassemblage-II correlates with Scheuringipollenites barakarensis palynozone in Tiwari and Tripathi (1992), and is correlatable with the palynoflora of Lower Permian in the Barakar Formation, Raniganj Coalfield (figure 3).

Palynodating: late Early Permian

Formation: Barakar Formation

\section{Discussion}

The characteristic palynocomposition of the Barren Measures Formation, i.e., dominance of Densipollenites (D. indicus, D. densus) along with striate bisaccate pollen taxa has not been recorded in the studied strata (231.10-408.40 m depths) in Borehole RT-4. This infers that lithologically delimited Barren Measures Formation is equitable with the youngest part of the Upper Permian, which is overlaying the Barakar Formation in the study area. Sudden decline of the Densipollenites shows a notable change in Barakar Formation.

Present palynological study in the borehole RT-4 supports the deposits of the Barakar Formation (late Early Permian), and further evidences the Raniganj Formation (Latest Permian). This negates the non-deposition of the Barren Measures Formation in the Tamra block, Raniganj Coalfield (table 3 and figure 3 ).

The morphological characters among the bisaccate pollen taxa and the dominance of Scheuringipollenites indicate cool climate in the beginning, which gradually warms up and becomes moderately warm with the dominance of Faunipollenites (Tiwari and Tripathi 1988) in the Barakar Formation. Also high humidity is indicated throughout the Barakar stage. On the basis of proliferation of striate bisaccate pollen taxa in the Barakar Formation, some seasonal fluctuations in the temperature and humidity are experienced (Tiwari 1973). This suggests that $547.00 \mathrm{~m}$ thick successions in the study area were deposited under warm with high humidity condition.

Besides, sedimentological studies indicate a warm temperature to subtropical in the lower part and tropical humid climate in the upper part of the Barakar Formation (Singh 1976). Megafloristically, warm-to-hot temperature climate was concluded (Lee 1976; Chandra and Chandra 1988). Mineralogical and oxygen isotope studies suggest humid climate during Early Permian Barakar Formation (Datta and Suttner 1986; Suttner and Datta 1986).

The palynological composition having dominance of bisaccate pollen along with an abundance of Densipollenites in the Raniganj Formation indicates warm climate with very high humidity throughout the span of Raniganj Formation (Tiwari and Tripathi 1988). This conclusion supports the presence of thick coal deposits in the Raniganj Formation. Besides, the faunal records also reveal temperature climates (Shah 1976).

\section{Conclusions}

The spore and pollen study of approx. $547.00 \mathrm{~m}$ thick litho-successions comprising the Barren Measures and Barakar Formations in Borehole RT-4, Raniganj Coalfield, concludes (figure 3 and table 3):

- Dark grey shales intercalated with siltstones between $30.75-227.80 \mathrm{~m}$ depths is referable to 
the Raniganj Formation of Late Permian in age, by presence of key species Densipollenites magnicorpus, Microbaculispora gondwanensis, Kamthisaccites sp., Arcuatipollenites sp.

- Abundance of hyaline, distorted blackish brown plant matter is observed between 231.00 and $408.40 \mathrm{~m}$ (ca $107 \mathrm{~m}$ depth), and that is devoid of palynomorphs. This might represent the Barren Measures Formation.

- Moreover, the Barren Measures Formation could not be proved palynologically between 30.75 and $423.80 \mathrm{~m}$ depths in the Tamara block, as delimited lithologically.

- Strata in between 419.95 and $577.70 \mathrm{~m}$ depths has yielded the conformable Barakar palynoassemblage which is late Early Permian in age.

- The palynocomposition recovered within $547.00 \mathrm{~m}$ thick succession in the study area, suggests the deposited sediments under warm with high humid condition.

\section{Acknowledgements}

One of the authors (S Murthy) expresses his gratitude to Dr Vijaya for her consistent encouragement in the preparation of this manuscript, and is thankful to Dr N C Mehrotra, Director, BSIP, Lucknow for the kind permission to publish this work. We extend our sincere thanks to the Dy. DG and officers of the Coal Wing Division, Geological Survey of India, Kolkata, for providing bore core samples for palynological study.

\section{References}

Bharadwaj and Tiwari R S 1977 Permian-Triassic miofloras from the Raniganj Coalfield, India; Palaeobotanist 24 $26-49$.

Chandra S and Chandra A 1988 Vegitational changes and their climate implications in coal bearing Gondwana; In: Concepts limits and extension of Indian Gondwana (eds) Venkatachala B S and Maheshwari H K, Palaeobotanist 36 74-86.

Datta P K and Suttner L J 1986 Alluvial sandstone composition and palaeoclimate. II. Authigenic mineralogy; J. Sedim. Petrol. 56 346-358.

Gee E R 1932 The geology and coal resources of the Raniganj Coalfield; Geol. Surv. India Memoir 61 1-343.

Lele 1976 Palaeoclimate implications of Gondwana floras; Geophytology 6 207-229.

Shah S C 1976 Climates during Gondwana Era in Peninsular India: Faunal evidence; Geophytology 6 186-206.

Singh I B 1976 Mineralogical evidence for climate vicissitudes in India during Gondwana times; Geophytology 6 174-185.

Suttner L J and Datta P K 1986 Alluvial sandstone composition and palaeoclimate, 1. Frame work mineralogy; J. Sedim. Petrol. 56 329-345.

Tiwari R S 1973 Scheuringipollenites, a new name for the Gondwana sporomorphs so far assigned to Sulcatisporites Leschik 1955; Senckenb Letb. 54(1) 105-117.

Tiwari R S and Meena K L 1992 Palynological sequence and relationship of subsurface Permian-Triassic sediments in eastern Raniganj Coalfield, West Bengal, India; Geophytology 21 21-32.

Tiwari R S and Tripathi A 1988 Palynological zones and their climate inference in the coal bearing Gondwana of Peninsular India; Palaeobotanist 36 87-101.

Tiwari R S and Tripathi A 1992 Marker assemblage zones of spore and pollen species through Gondwana Paleozoic and Mesozoic sequence in India; Palaeobotanist 40 $194-236$. 